\title{
THE SO-CALLED “MITHRAIC CAVE” OF ANGERA
}

\author{
A NEW PERSPECTIVE FROM ARCHAEOLOGICAL \\ INVESTIGATIONS
}

\begin{abstract}
Summary: The existence of a mithraeum at Angera (VA, Italy) was assumed for the first time in the 19th century, after the discovery of two Mithraic inscriptions re-used as ornaments of a private garden in the middle of the small town. The location of the alleged mithraeum is still uncertain: the inscriptions have been found out of context, and the place of worship has never been localized.

The "Antro mitraico" (Mithraic Cave), also known as "Tana del Lupo", is a natural cave situated at the base of the East wall of the cliff on which the Rocca Borromeo (the Castle of Angera) stands. At the cave the most visible archaeological evidences are tens of breaches cut into the outside rocky wall, which probably contained votive inscriptions or stele. These elements denote the use of the cave as a place of worship.

In 1868 Biondelli identified in the cave the location of a Mithraic cult, giving rise to a theory that continues still today. If, on the one hand, the proposal appeared plausible, there is no clear evidence that in the cave a mithraeum was ever set up; besides, the presence of many an ex voto is in conflict with the mysteric ritual practices. This paper is intended to present an analytical study of the monument, with a broader inquiry on the characteristics of mithraea and other sanctuaries within natural caves.
\end{abstract}

Key words: Angera, Tana del Lupo, Roman religion, Roman cult cave

At present, Angera is a small village at the center of the southern shore of the Lago Maggiore, also known as Verbano Lake, in the province of Varese, Italy, above the rocky cliff of Rocca Borromea (figs 1-2). We have only a partial archaeological evidence concerning the settlements in this area during the Roman period (they were either one or more than one, shaped as vici). ${ }^{1}$ On the other hand, we have a large burial

${ }^{1}$ On Roman Angera and its territory cfr. RATTI, E.: Sebuinus Vicus. Ricerca pilota, analitica e stratigrafica su un villaggio della Cisalpina. Atti Centro Studi e Documentazione sull'Italia Romana 6 (1974-75) 199-250; Sena ChiesA, G. - LAVIZZARi PedrazzInI, M. P.: Angera romana. Scavi nell'abitato 19801986. Roma 1995; GRASSI, B.: Angera (VA). Le più recenti ricerche nel centro abitato. Nuovi dati sulla topografia del vicus romano. In DE MARINIS, R. C. - MASSA, S. - PIZZO, M. (edd): Alle origini di Varese e del suo territorio. Roma 2009, 323-349; DAVID, M. - MARIOTTI, V.: Da Kaprotabis ad Angera. L'epigrafe funeraria di un siriano ai piedi delle Alpi. Syria 82 (2005) 267-268; SENA CHIESA, G.: Angera, un vicus romano fra leggenda e realtà archeologica. In HARARI, M. (ed.): La Storia di Varese. III/2: Il territorio di Varese in età romana. Varese 2014, 60-82. 


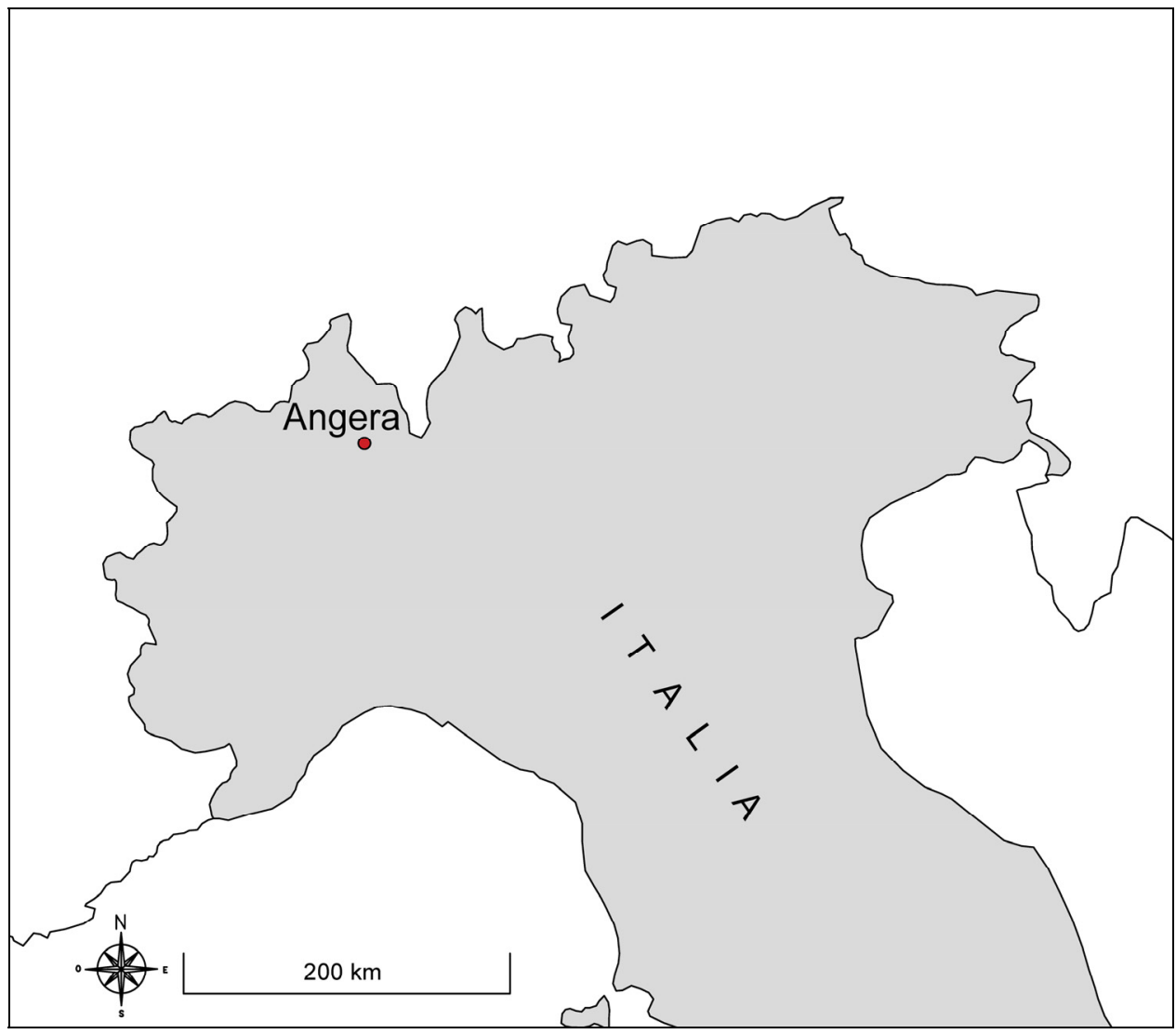

Fig. 1. Map of Northern Italy, with Angera singled out (S. De Togni).

ground, a necropolis in use from the Augustan Age to the 3rd century AD, which have been brought to light in the past century. ${ }^{2}$ Several factors favored the flourishing of the area, included in the Mediolanum's territory, such as its role of a crossroad for both Roman roads and the numerous river and lake itineraries in the Ticino and Verbano areas, and the exploitation of rocky layers of dolomite stone with large quarries on the western side of the Angera hill. ${ }^{3}$

An unsolved problem is that of the ancient toponym, because the proposed names of vicus Sebuinus, Statio for the area of Angera are actually of uncertain location. ${ }^{4}$

${ }^{2}$ Bertolone, M.: Lombardia romana. Vol. II. Milano 1939, 88-93, tav. II; SENA ChIESA, G. (ed.): Angera romana. Scavi nella necropoli 1970-79. Roma 1985.

${ }^{3}$ DAVID, M. - DE Michele, V.: Remarques sur les matériaux lithiques exploités en Lombardie à l'époque préindustrielle. In SCHVOERE, M. (ed.): Archeomateriaux. Marbres et autres roches. ASMOSIA $I V$. Actes de la IV Conférence internationale de l'Associaton pour l'étude des marbres et autres roches utilises dans le passé, Bordeaux-Talence, 9-13 ottobre 1995. Bordeaux 1995, 269-284.

${ }^{4}$ RATTI, E.: La ricostruzione di Stazzona e il vico Sebuino. Atti Centro Studi e Documentazione sull'Italia Romana 4 (1972-73) 9-82. 


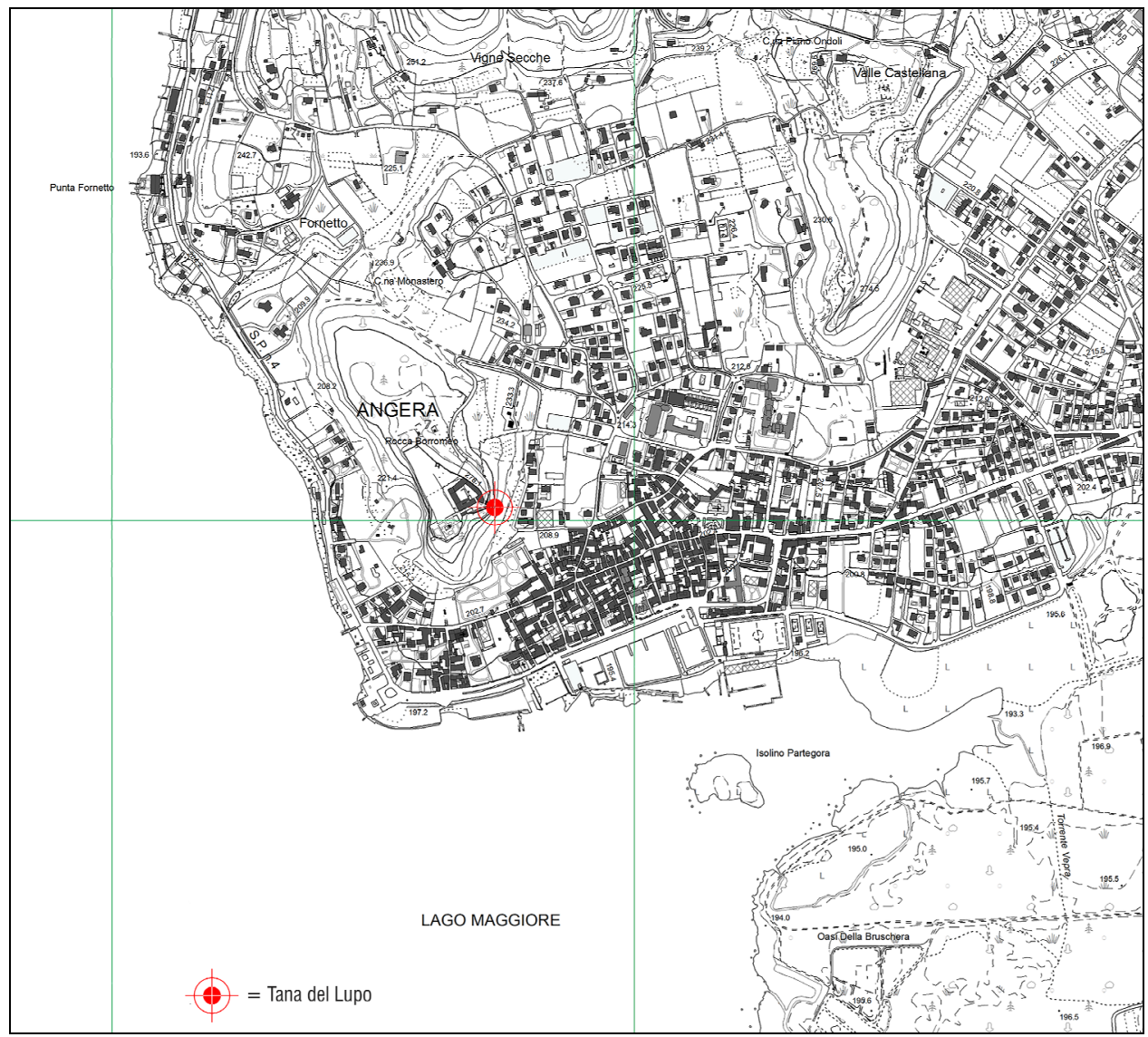

Fig. 2. Map of the territory of Angera with localization of the Tana del Lupo (S. De Togni from Carta Tecnica Regionale 1:10000 of the Lombardy Region)

Numerous votive and funerary inscriptions, and architectural fragments have been collected from this zone, ${ }^{5}$ probably thanks to antiquarians' collections. Several altars with dedications to gods elsewhere known from the Cisalpine Gaul testify to a local religious fervor. Five altars to Jupiter Optimus Maximus came from Angera, ${ }^{6}$ three to Mercury, ${ }^{7}$ three to the Matronae, ${ }^{8}$ two to Hercules, ${ }^{9}$ one to Silvanus, ${ }^{10}$ and one to Isis. ${ }^{11}$

${ }^{5}$ SENA CHIESA, G.: Candida marmorum fragmenta. Spunti di ricerca su alcuni rilievi romani ad Angera. In Studi in onore di Mario Bertolone. Varese 1982, 111-125.

${ }^{6}$ CIL V 5470-5474.

${ }^{7}$ CIL V 5478-5480.

${ }^{8}$ CIL V 5475-5476; GIUSSANI, A.: Nuove iscrizioni romane e cristiane di Angera e dintorni. Rivista Archeologica antica Diocesi Como 76-78 (1917-1918) 71-75.

${ }^{9}$ CIL V 5466; CIL V 5467/8.

${ }^{10}$ CIL V 5481.

${ }^{11}$ CIL V 5469. 
Six fragments of limestone chiseled columns, discovered during the 19th century in the square of the parish church of Angera, are kept in the Civic Museum of Villa Mirabello at Varese, and they probably belonged to two twin monumental columns of the ancient settlement. ${ }^{12}$ They are rare in both Italy and the Cisalpine Gaul, whereas they are rather common in the Transalpine provinces, where they were used in arches or small cultic buildings. ${ }^{13}$

Two Mithraic inscriptions were discovered in Angera, as well, in the 19th century. The most famous one is now kept in Milan and was brought to light by Bernardino Biondelli in 1868 in a private garden abutting the parish church. ${ }^{14}$ It is a base of a statue of Cautopates made by two Mithraic leones. ${ }^{15}$ The measures of this base are $36 \times 40 \times 48 \mathrm{~cm}$, and therefore the estimate height of the statue is of ca. $50 \mathrm{~cm}$ (fig. 3). The second monument is lost ${ }^{16}$ and consisted in an inscription re-used in the St Alessandro church, bearing the abbreviated dedication to Mithras D(eo) S(oli) I(nvicto) $M\left(\right.$ ithrae) by a Valerianus Petalus. ${ }^{17}$ Unfortunately, these pieces are out of their original context.

One among the most interesting and controversial ancient monuments from Angera is the so-called Tana del Lupo ("Lair of the Wolf", figs 4-6). It is a natural cave whose opening is located at the foot of the rocky hill of the Rocca Borromeo. The archaeological research proved an human frequentation of the cave from the pre-historical period. ${ }^{18}$ Monumental buildings were added in the Roman Age, when the rocky slope framing the cave's mouth was carved with niches for inscriptions or votive reliefs of different sizes, whose holes for the fixing clamps are still visible. Some square holes, probably postholes from the building site, are preserved, and some traces of architectural decoration of the entrance, as well. The latter and the interior were modified in order to regularize their form. These evidences suggest the ancient use of the site as a cultic place.

In 1868, when the base with its dedication to Cautopates was discovered, Bernardino Biondelli discovered, or, rather, located the cave, and interpreted it as a Mithraic spelaeum, due mainly to the misunderstanding of the features of the place. ${ }^{19}$ After the discovery of the cave, Franz Cumont visited it and inserted it in his great catalogue

\footnotetext{
${ }^{12}$ SENA CHIESA: Candida marmorum fragmenta (n. 5) 114-116.

${ }^{13}$ WALTERS, H.: La colonne ciselée dans la Gaule romaine. Paris 1970, in part. 72-76; SENA CHIESA: Candida marmorum fragmenta (n. 5) 115.

${ }^{14}$ CIL V 5465; BIONDELLI, B.: Iscrizioni e monumenti romani scoperti ad Angera sul Verbano. RIL I (1868) 523.

${ }^{15}$ Cautopati sac[r(um)] / M(arcus) Status Niger] / VI vir aug(ustalis) c(reatus) d(ecreto) d(ecurionum) [M(ediolanensium)] / [col]leg(ium) dend(rophorum) c(oloniae) A(ureliae?) A(ugustae?) M(ediolanii) / et C(aius) Valerius Iulia(nus?) / leones leg(ati?) v(otum) s(olverunt) l(ibentes) m(erito). Cfr. CIMRM 718.

${ }^{16}$ CIL V 5477; BIONDELLI (n. 14) 527.

${ }^{17}$ D(eo) S(oli) i(nvicto) M(ithrae) / adiutor(i) / Valerian(us) / Petalus v(otum) [s(olvit)]. Cfr. CIMRM 717.

${ }^{18}$ BASERga, G.: Scavi ad Angera. Preistoria. RAComo 76-78 (1917-1918) 31-46; PATRONI, G.: Angera. Scavi nell'antro mitriaco. NSA XV (1918) 3-11; FUSCO, V.: Ricerche preistoriche nel territorio di Angera. In Studi in onore di Mario Bertolone. Varese 1982, 1-38.

${ }^{19}$ BiONDELLi (n. 14) 528-531.
} 


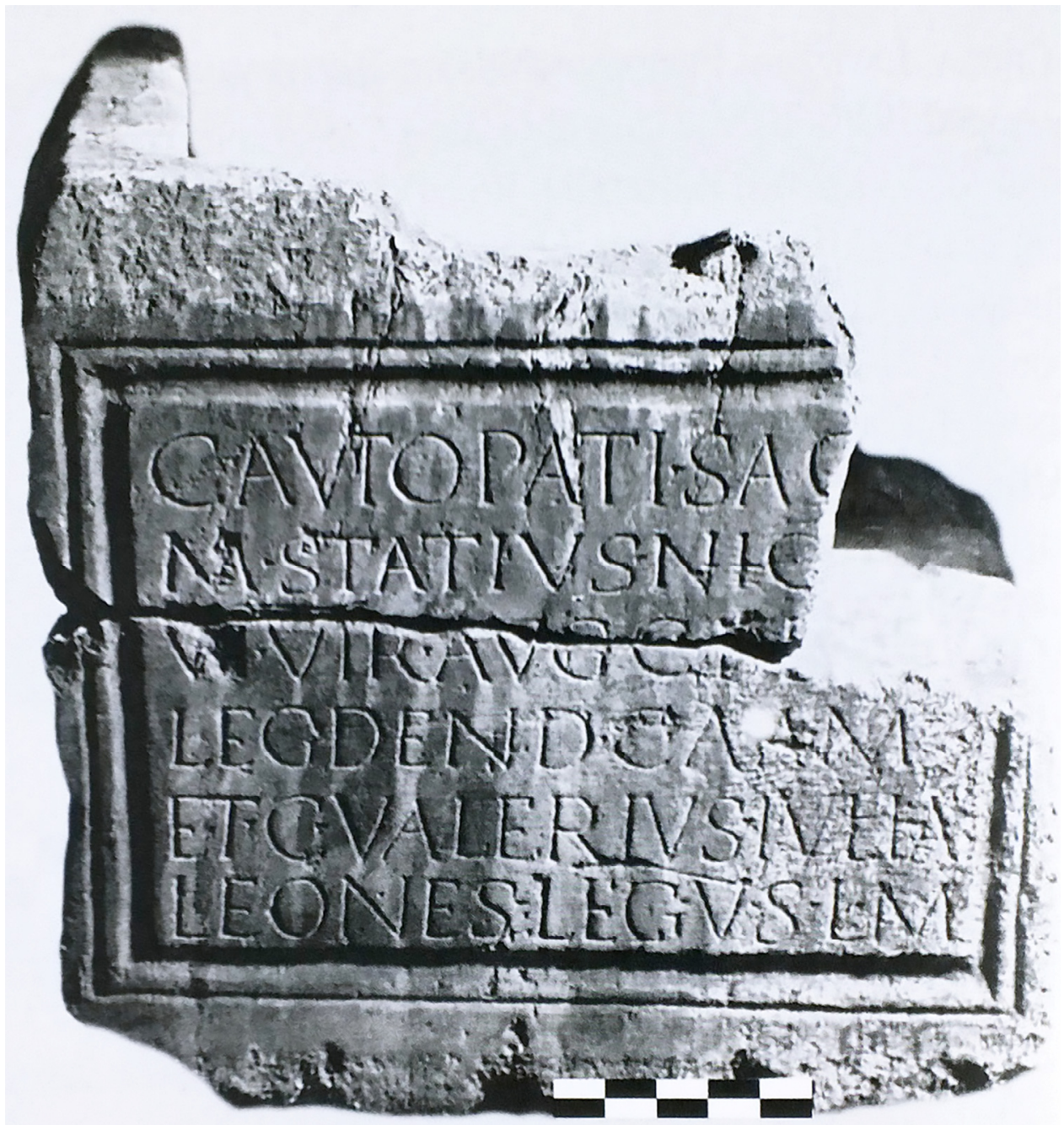

Fig. 3. Base of a statue of Cautopates $(C I L$ V, 5477, from SARTORI, A.: Le pietre iscritte di Angera. In DE MARINIS, R. C. - MASSA, S. - PIZzO, M. [edd]: Alle origini di Varese e del suo territorio. Roma 2009, 364-370).

of $1896 .{ }^{20}$ Since then, the cave was generally acknowledged as a mithraeum and called Antro Mitriaco. ${ }^{21}$ This interpretation, after discoveries concerning Mithraism and mithraea over more than one century, raises doubts and perplexities because no proof exists suggesting a Mithraic use for this cave, and, moreover, the numerous external votive niches contrast with the known rituals of mystery religions.

${ }^{20}$ Cumont, F.: Textes et monuments figurés relatifs aux mystères de Mithra. Tome II. Bruxelles 1896, 262-264, n. 109.

${ }^{21}$ Also Vermaseren added it to his corpus of the Mithraic monuments (CIMRM 716). 


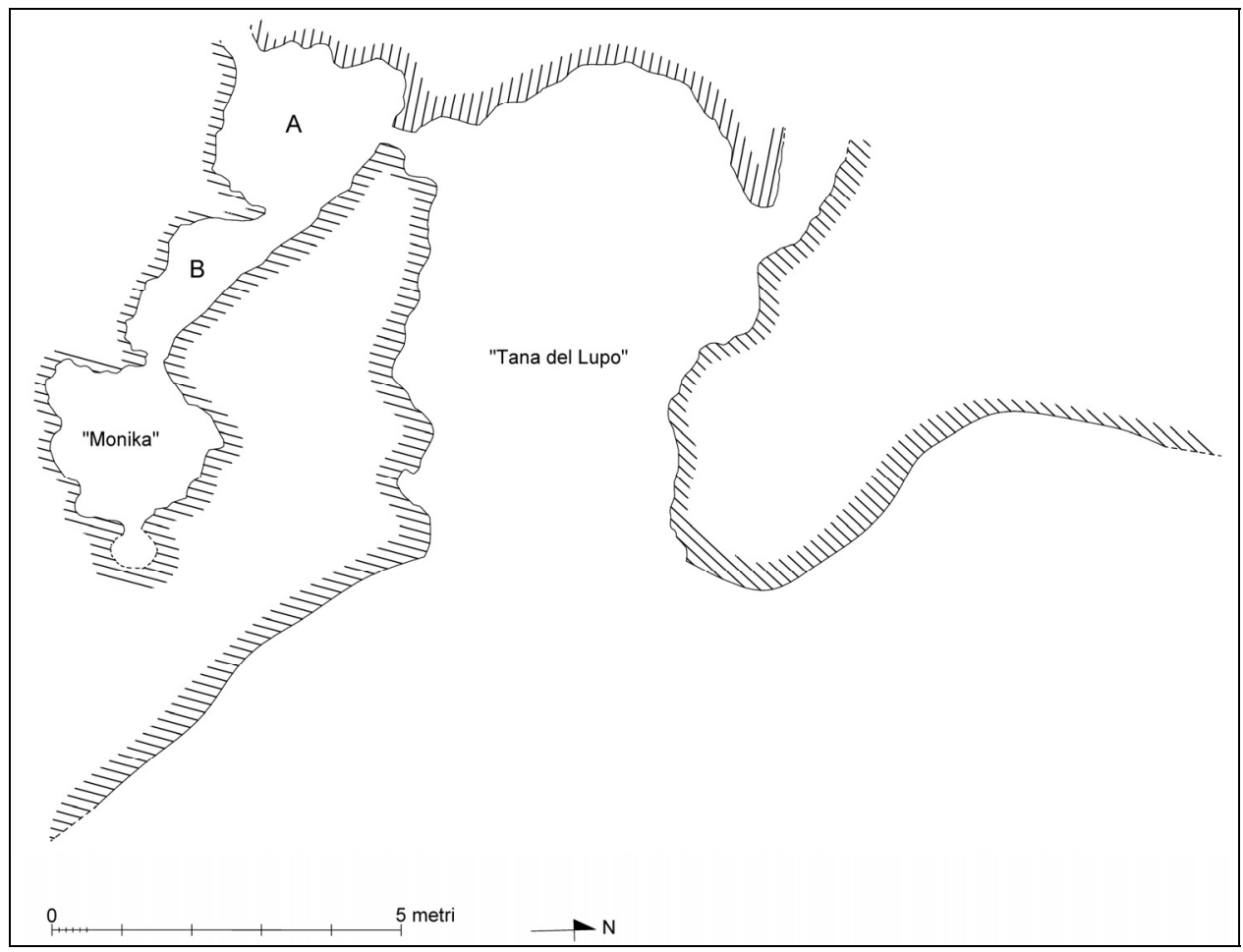

Fig. 4. Angera, Tana del Lupo. Planimetry (S. De Togni, 2009).

Further information concerning this monument can be gathered from the history of the research. In 1916, the Società Archeologica Comense, with his president Antonio Magni, promoted excavations inside the cave. The digging took place in June under the direction of Giovanni Patroni, the Sovrintendente agli scavi e ai musei lombardi, and Giovanni Baserga, vice-president of the Archaeological Society, and its secretary Antonio Giussani, were at work as well. ${ }^{22}$ The anthropic layers were almost completely removed in the cave, but the reports, even though very analytic, are often too short and allow only a partial reconstruction of the stratigraphy. Before the digging, the floor level was about $130 \mathrm{~cm}$ higher than now, and the removed earth was heaped up outside of the cave, and consequently the spot has been deeply modified.

On the modern surface inside the cave the archaeologists discovered fragments of tiles and bricks and traces of relatively recent fires. At the depth of $70 \mathrm{~cm}$ a beaten earth floor was brought to light, covered by a layer rich in heterogeneous materials, including medieval ceramics. ${ }^{23}$ Patroni mentioned then a muretto antico cementato

22 BASERGA (n. 18) 32.

${ }^{23}$ Patroni listed the materials discovered in the upper layer: remains of medieval glazed ceramics, fragments of tiles and Roman bricks, sherds of terracotta vases and soapstone vases of different size and shape, an iron spear's head, an iron key, and many bone remains from bovine, sheep and pigs; PATRONI (n. 18) 5-6. 


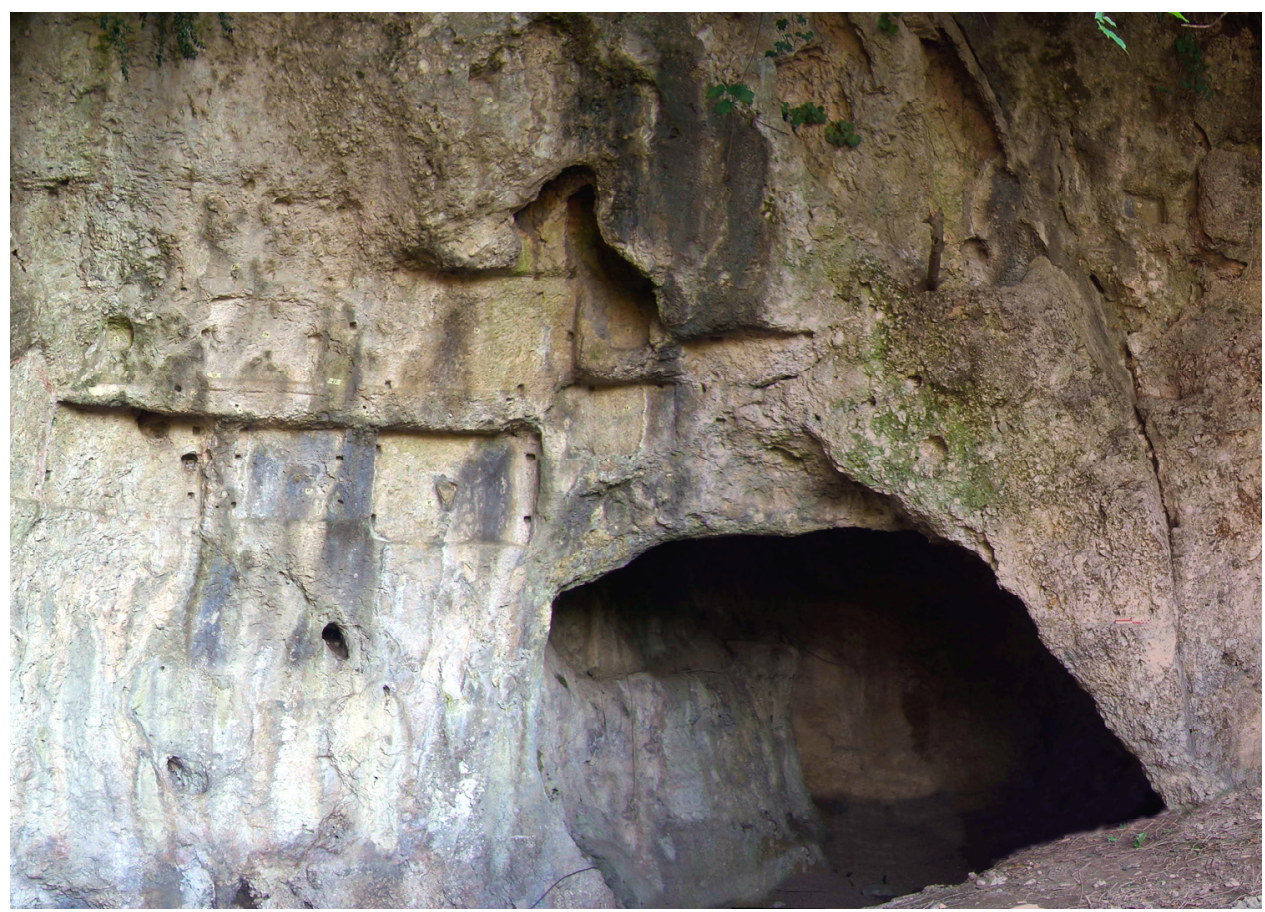

Fig. 5. Angera, Tana del Lupo from the east (photo by S. De Togni, 2009).

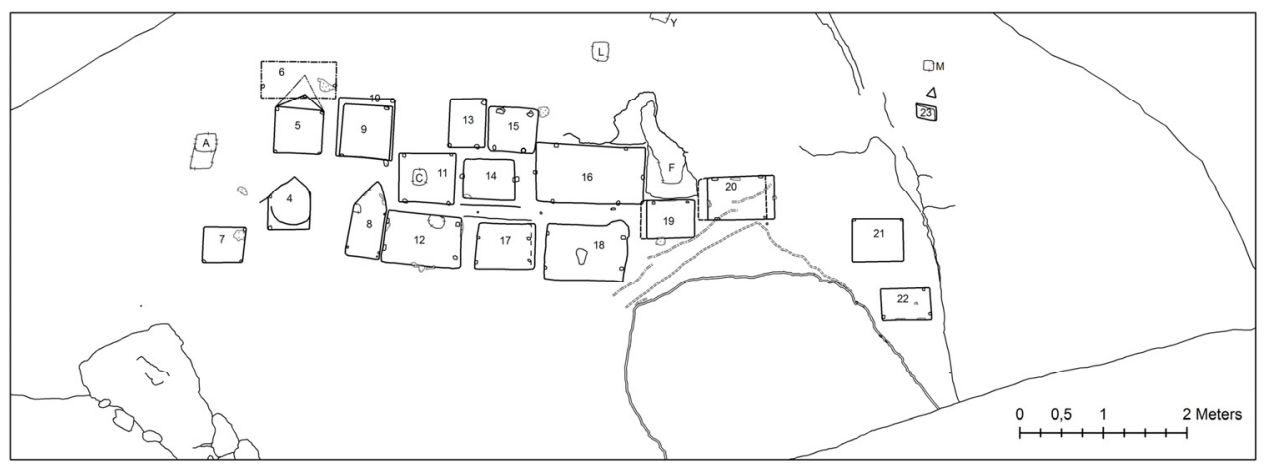

Fig. 6. Drawing of the outer cliff of the Tana del Lupo (from M. DAVID - S. DE TOGNI 2008-2009 [n. 39]).

con calce (a small ancient wall built with mortar) on the right, close to the back wall. ${ }^{24}$ A large hearth $(2.00 \times 0.60 \mathrm{~m})$ was discovered close to the back wall, with its base made of stones blackened by smoke and fire. Another smaller hearth $(1.00 \times 0.80 \mathrm{~m})$ was

${ }^{24}$ It is obscure whether this small wall had been unearthed in this digging phase or it was yet visible on the soil. This latter hypothesis is less probable because Cumont, in 1896, did not describe it; CUMONT (n. 20) 263. 
found near the entrance, on the right, and two other little fireplaces (ca. $0.60 \times 0.60 \mathrm{~m}$ ) were discovered outside the cave. The excavation proceeded to digging a trench (according to Baserga 0.60 wide $\times 5 \mathrm{~m}$ long), going orthogonally to the entrance in order to explore the soil from this point to the back wall, by running along the cave on its left side. ${ }^{25}$ After having removed a layer $60 \mathrm{~cm}$ thick, including pre-historic and Roman materials mixed together, a more ancient floor was reached. It was a beaten earth floor, irregular, and leaning towards the entrance.

The layer between the two floors was made of terriccio sabbioso giallastro (sandy yellowish earth) including many bone remains and lake oyster shells (Unio vulgaris), interpreted as meal remains. ${ }^{26}$ Patroni mentions a series of sherds of Roman ceramics, ${ }^{27}$ glass, ${ }^{28}$ and many finds which he labels prehistoric. ${ }^{29}$ Subsequently, the excavation removed another $65 \mathrm{~cm}$ of earth but we do not know where it occurred. However, the mention of the hearths and parts of a floor preserved in situ suggests that the digging had been narrow, perhaps only on the left of the entrance. After that, an "ammasso di pietrame tra cui grossi pezzi di calcestruzzo romano con frammenti di cotto"30 (a dump of stones including pieces of Roman concrete with terracotta sherds) was found. According to Patroni this material was the result of the demolition of a building, and adds that "con questi pezzi e con sassi si era costruito un muro a secco, che restringeva l'ingresso, in cui sarà stata lasciata una porticina",31 (with those pieces and with pebbles a dry stone wall was built, which narrowed the entrance, where a door had to be installed). At this level a noteworthy amount of Roman coins was discovered, to a total of 266. Unfortunately, the circumstances of the finding are obscure, and it is difficult to evaluate precisely how it was enacted. We can only realize from the documentation that many coins were near the dump by the threshold, and other ones are said to have been found in the trench. Now they are lost, but were studied and published by Ludovico Laffranchi, ${ }^{32}$ who listed them precisely. ${ }^{33}$ They

${ }^{25}$ BASERGA (n. 18) 38.

${ }^{26}$ PATRONI (n. 18) 6.

27 "...dolii, anfore vinarie, brocche, scodelle, piatti, lucerne, vasi aretini o d'imitazione" (large jars, wine amphoras, pitchers, bowls, dishes, lamps, Arretine vases or their imitations); PATRONI (n. 18) 6.

28 “....frammenti di vasetti di vetro, talora decorati a rete geometrica in rilievo, di varie forme. Tra questi frammenti vitrei riconobbi gli avanzi di un piatto, di un vaso con rilievi a cordone disposti a festoni, di una coppa ornata a rete di esagoni in rilievo, di un vasetto decorato ad impressioni regolari; finalmente orli di tazzine, piedi di vasetti ecc." (fragments of glass vases, of various shapes, sometimes decorated with a relief net. Among them I recognized remains of a dish, of a vase with a "cord chains decoration", a cup with hexagonal decoration relief, a small vase with regular impressions, and rims of cups and bases of small vases). PATRONI (n. 18) 6.

${ }^{29}$ They were flint awls, hundreds of flint splinters and the related cores, a bone awl, a fragment of stone ax-hammer, a fragmentary stone mace, three sherds of "prehistoric" clay artifacts, a fragment of a granite mill, with no dating; PATRONI (n. 18) 10-11.

${ }^{30}$ PATRONI (n. 18) 6.

${ }^{31}$ PATRONI (n. 18) 6.

${ }^{32}$ LAFFRANCHI, L.: L'antro mitriaco di Angera e le monete in esso rinvenute. Bollettino italiano di Numismatica e Arte della Medaglia 14.4 (1916) 49-55.

${ }^{33}$ One as of Vespasian, of $73 \mathrm{AD}$, one of Marcus Aurelius Caesar, of 154, one of Faustina Senior, of 141, one sestertius of Otacilia datable to 246-247, nine Antoniniani of Gallienus (the earliest of whom is datable to ca $264 \mathrm{AD}$ ), two of Claudius II, one of Quintillus, one of the Caesar Carinus, one of Diocletian, of 285, 14 coins of Costantine, 21 of Costans I, one of Magnentius, 40 of Costantius II, 6 of 

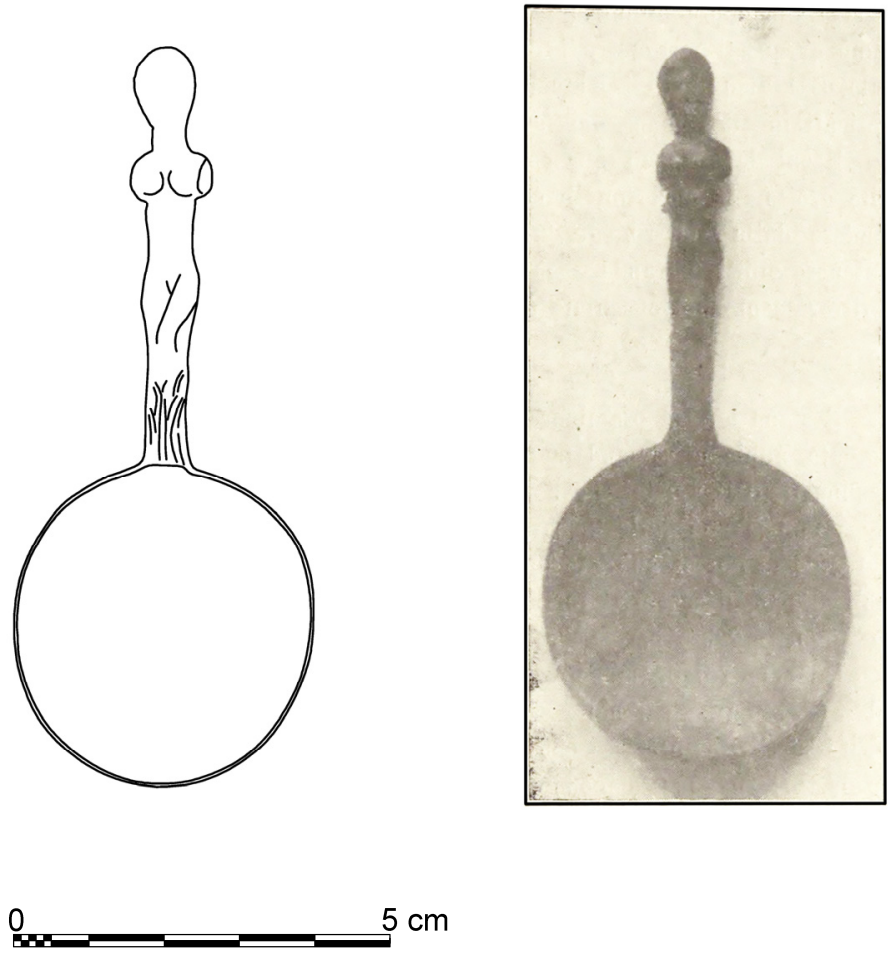

Fig. 7. The bronze spoon found in 1916 (at present, lost). Drawing from the photograph, and the photograph itself (created by S. De Togni from BASERGA [n. 18]; photo from PATRONI [n. 18]).

were mostly late antique items, datable to between the mid-4th and the beginning of the 5 th century AD.

Another big trench $(6 \times 2 \times 1.50 \mathrm{~m})$ was dug out of the cave, along the left slope of the cliff. Close to the cliff two tombs of adults, with no funerary goods, were unearthed along with sundry materials from muddled layers, and, in particular, six pieces of quartz, a fragment of metal foil from the neck of a vase, fragments of bronze nails, iron nails, one uncinetto snodato in ferro (one small articulated iron hook), fragments of an iron knife, one peculiar bronze spoon with hemispherical cup, short shaft in the shape of a half-naked woman, carved from the knees to the head. The spoon, published shortly after its discovery, ${ }^{34}$ is lost. From the unique image with a scale, it is possible to obtain the dimensions of $9.2 \times 4 \mathrm{~cm}$. It is a small spoon datable to the 1 st century $\mathrm{AD}^{35}$ (fig. 7 ).

Costantius Gallus, 5 of the Caesar Julian, one of Julian Augustus, 38 pf Valentinianus I, 31 of Valens, 6 of Gratianus, 6 of Valentinianus II, 5 of Theodosius, 2 of Magnus Maximus, one of Honorius, three of Arcadius, one of Valentinianus III, and other 67 coins whose classification was impossible, but they are datable between the 4th and the 5th centuries AD. LAFFRANCHI (n. 32).

${ }^{34}$ PATRONi (n. 18) 7, fig. 3; BASERGA, G.: Scavi ad Angera. Il culto mitriaco. RAComo 76-78 (1917-1918) 47-67, fig. 8.

${ }^{35}$ STRONG, D. E.: Greek and Roman Gold and Silver Plate. London 1966, 155. 
No trace was found of the slabs which were placed in the niches outside of the cave, with the exception of two small marble fragments, one of which has no inscription, and the second which had the letters ifex / on, wherein Patroni recognized (pont)ifex/on.

In 1973, almost 60 years after the excavation, Vincenzo Fusco carried out new diggings, ${ }^{36}$ which took into account the part of the beaten soil which was not dug previously, i.e., the right half of the cave. He found the interface created by a circular container whose diameter was ca. $70 \mathrm{~cm}$, which was placed close to the right wall, in association with Roman materials. Fusco also explored the system of lateral rooms, to which a small opening in the left face of the cave led, as in the maps of $1947 .{ }^{37} \mathrm{He}$ discovered there a small room, previously unknown, which was called Grotta Monika ${ }^{38}$ (fig. 4).

In 2009, further archaeological investigation was carried out by the Archaeological Department of the University of Bologna, in co-operation with the Soprintendenza archeologica della Lombardia and the Civic Museum of Angera. The research focused on the area outside of the cave, mapped the rocky cliff, analysed systematically every visible trace on the surface, and dug the remaining stratigraphies. ${ }^{39}$ From the new mapping result that the cave is $7.50 \mathrm{~m}$ long, $4.70 \mathrm{~m}$ wide, $4.80 \mathrm{~m}$ high; its entrance is $30 \mathrm{~m}$ higher than the modern Angera. Inside, on the southern face, at $2 \mathrm{~m}$ from the soil, a narrow tunnel leads to the lateral rooms. Another tunnel is open in the northern face and goes up toward the West to provide the cave with light, thanks to a split in the dome. The interior of the cave is in some places covered by limestone deposits created by the dripping water. This phenomenon can be seen also in the narrow lateral rooms, where some stalactites are preserved.

The excavation has documented stratigraphies referring to the remains of Mesolithic human frequentation, whereas all the upper layers referring to the historical period had been already removed in the previous digging. The analyses of the outer cliff documented 20 interfaces of no longer existing stone slabs, whose dimension varies from $40 \times 60 \mathrm{~cm}$ to $70 \times 125 \mathrm{~cm}$ (fig. 6). They were rectangular, only two with an apex, and were affixed to the rock by means of clamps fastened with either lead or mortar, and many holes which hosted them are still visible. ${ }^{40}$ In one case traces of lateral finishing with red plaster have been detected. The research of traces of the structural development of the entrance suggested the hypothesis of a protruding external building, probably a small pronaos $3 \mathrm{~m}$ high and $4 \mathrm{~m}$ wide (fig. 8).

\footnotetext{
${ }^{36}$ FUSCO (n. 18).

${ }^{37}$ The first mapping of the cave was made in 1947 by P. Cozzi and B. Fiorina, members of the Gruppo Grotte di Milano.

${ }^{38}$ FUSCO (n. 18).

${ }^{39}$ DAVID, M. - De Togni, S.: Tana del lupo. Nuove ricerche. Notiziario della Soprintendenza archeologica della Lombardia 2008-2009, 239-241; DAVID, M. - DE TOGNI, S.: La Tana del Lupo di Angera. In HARARI, M. (ed.): La Storia di Varese. III/2: Il territorio di Varese in età romana. Varese 2014, $180-181$

${ }^{40} 67$ holes for the fixing clamps have been documented, several of them with traces of lead or mortar inside.
} 


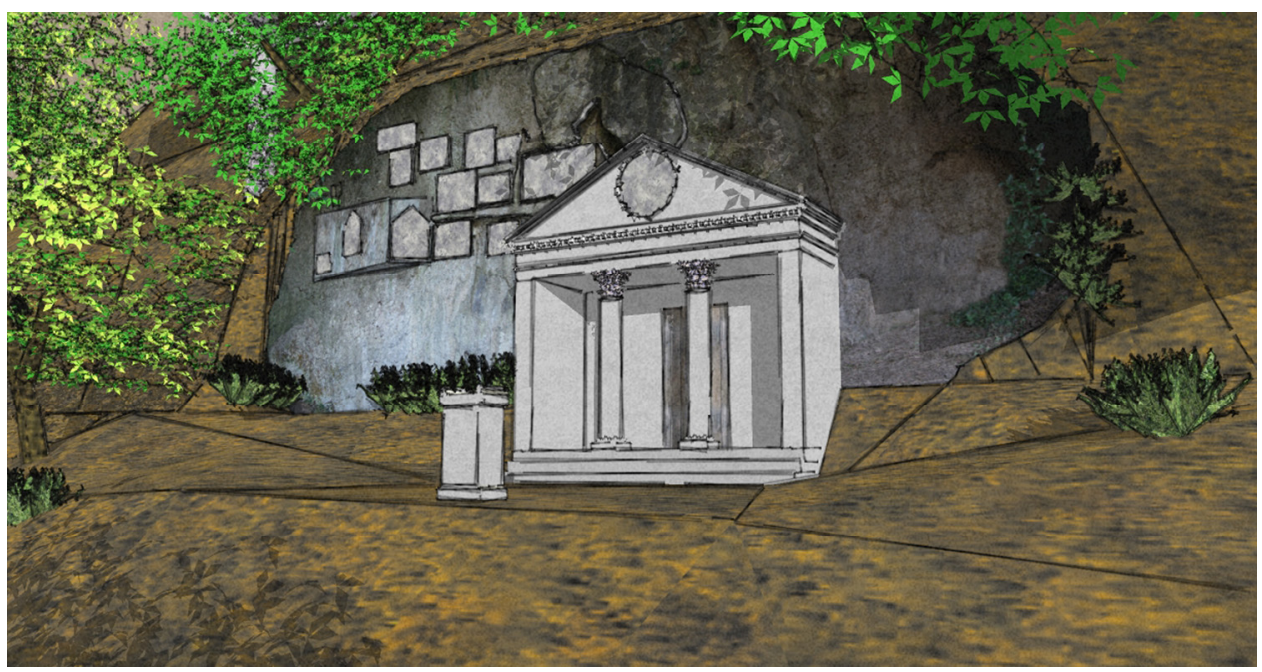

Fig. 8. Reconstruction of the possible shape of the Tana del Lupo in the Imperial Age (created by S. De Togni - M. David).

The Tana del Lupo of Angera should have been similar to the Roman Age sacred caves, where maybe particular therapeutic waters were revered, and ex votos were laid. ${ }^{41}$ Such a scenario is also suggested by the basin discovered close to the

${ }^{41}$ Often the cave was, in the Roman world - as a survival of prehistoric times - the seat of a deity. The natural elements (deep caves, dripping water, darkness...) inspired the humans with feelings of divine presences, as if it was the dwelling of numina; LAVAGNE, H.: Operosa antra. Recherches sur la grotte à Rome de Sylla à Hadrien. BEFAR 272 (1988) 189-201. Numerous natural caves are documented in the Roman Empire, where traces - sometimes hardly classifiable - of ancient cults have been discovered; MARCATTILI, F.: Spelaeum. In ThesCRA IV (2005) 332-335. For example, the Grotta Lattaia of Monte Cetona (Siena) was named so after some pretended properties of the dripping water for human breastfeeding (this belief lasts from the antiquity to nowadays); inside dozens of imperial age ex votos have been discovered (statuettes, votive breasts, coins): CALZONI, U.: Recenti scoperte a Grotta Lattaia sulla montagna di Cetona. StEtr 14 (1940) 301-304; the cave "Cueva Negra" (Fortuna, Spagna) is a system of three caves where many votive inscriptions have been discovered (tituli picti) dated to the 2nd century $\mathrm{AD}$, which were painted red on the cliff and consist of dedications to the Nymphs, to Bacchus and to Magna Mater (STYLOW, U. - MAYER, M.: Los Tituli de la Cueva Negra. Lectura y comentarios literario y paleográfico. Antigüedad y Cristianismo 4 [1987] 191-235); the Grotta Porcinara or Portinara (S. Maria di Leuca, Lecce), is a partially natural cave opened towards the sea cliff where numerous inscriptions were cut on the rock, which have been dated to between the 6th century $\mathrm{BC}$ to the $2 \mathrm{nd} \mathrm{AD}$, and seem to refer to a Iuppiter / Zeus as the divine owner of the cave (PAGLIARA, C.: La Grotta Porcinara al Capo di S. Maria di Leuca. Annali dell'Università di Lecce 6 [1971-73, 1974] 5-67). Numerous cave sacred to the Nymphs are known and they were often caves with architectural additions such as in the case of the cave of Vari, in Attica (Weller, C. H.: The Cave at Vari. Description, Account of Excavation and History. AJA 7 [1903] 263-288), or that of Grotta Caruso (Locri, Calabria) wherein a series of niches for votive offerings had been cut, and close to its entrance a semi-circular basin had been cut in order to keep water, and its exterior was decorated with a kind of small portico with two slopings; MARTORANO, F.: La Grotta Caruso. In CosTABILE, F. (ed.): I ninfei di Locri Epizefiri: architettura, culti erotici, sacralità delle acque. Soveria Mannelli 1991, 7-15. 
right wall and the bronze spoon unearthed in 1916. On the contrary, no feature of a typical mithraeum has been noticed. ${ }^{42}$

Recently, Cristina Miedico underlined the association of the Matronae - goddesses of Gaulish tradition - with the Nymphs and with the Roman Iunones. ${ }^{43}$ As the cult of the Nymphs is not witnessed in Angera, she proposes that the cave had been a cultic place for the Matronae because three votive altars to these goddesses have been found in this zone. ${ }^{44}$

The stratigraphic record by the archaeologists of the past centuries, even if scarce, allows to add further remarks. It is possible to reconstruct an early phase, most likely in the 1 st century $\mathrm{AD}$, corresponding to the monumental reshaping of the cave, when the first floor was laid.

In the second phase, the soil was raised ca. $60 \mathrm{~cm}$ and made smoother, thanks to a beaten earth floor. As the finds show, this layer was probably added in the 3rd century $\mathrm{AD}$ or shortly later. We cannot ascertain whether the cave was still a cultic place in this phase, even though this seems to be probable because of the deposition of the large basin discovered by Fusco.

${ }^{42}$ The relationship between Mithraism and cave is complex and refers to the origins themselves of the cult, and it is impossible to deal with such a multifaceted problem in this paper. In order to deal shortly with it, we can say that spelaeum was the name of the cultic halls of Mithraism, but, on the other hand, the true natural caves for mithraea are few, and the mithraea were mostly buildings; ROMIZZI, L.: Mithraeum. In ThesCRA IV (2005) 275-280. The word spelaeum did not refer to a natural cave but simply remembered, in an idealized way, the mythical "Persian" one where Mithras was born. It was rich in soteriological meanings and was the place for the mysteries celebrated by the devotees. The memory of the Zoroastrian cave involved the shape of the mithraea, which were often underground or partially underground rooms, often made out of pre-existing buildings, and therefore they were deprived of a monumental outer form. Spaces and furniture of these special cultic halls had a peculiar order, according to recurring and almost standard features which alluded or symbolised the heavens and its cycles. They were elongated and narrow rooms with side podia (or praesepia) for the ritual meals. On the backwall an image of the Tauroctony was on display and it was also depicted as if it had taken place in a cave. Close to it an altar stood. One among the few natural caves for mithraea is that of Duino (Trieste). Here side benches of masonry and remains of a true roof with tiles inside the cave have been found, along with fragments of a relief depicting the Tauroctony and several small votive altars dedicated to Mithras; PROSS GABRIELLI, G.: Il tempietto ipogeo del dio Mitra al Timavo. Archeografo Triestino 35 (1975) 5-34. The difference between this latter cave and the Angera cave is evident: in fact, the space inside the cave of Duino had been artificially re-shaped and occupied by the building of the mithraeum himself and no trace of votive offerings and ex votos is visible outside. There are then examples of Mithraea created in natural rocky locations, but not properly in caves. This is the case of the mithraeum of Schwarzerden, in Germany (CIMRM 1280; Cumont [n. 20)] 383, n. 258) and that of Bourg-saint-Andéol, in France (CIMRM 895, 896, 897; Cumont [n. 20] 401, n. 279). Here the Mithraic relief had been cut on the cliff, but the mithraeum itself was added as a buiding abutting the cliff. Some mithraea were artificial underground rooms re-shaped for the cultic activities, and this is the case of the mithraeum of Marino (VERMASEREN, M. J.: Mithriaca III. The Mithraeum at Marino [EPRO 16]. Leiden 1982), made out of a cistern in the tufic bedrock, and the Mithraeum of Doliche (SCHÜTTE-MAISCHATZ, A. - WINTER, E.: Die Mithräen von Doliche. Überlegungen $\mathrm{zu}$ den ersten Kultstätten der Mithras-Mysterien in der Kommagene. Topoi 11.1 [2001] 149-173), made in the tunnels of an abandoned mine.

${ }^{43}$ Miedico, C.: Dee che danzano. Le Matrone di Angera e le altre. In GARANZINI, F. - POLETTI ECCLESIA, E. (edd): Fana, aedes, ecclesiae: forme e luoghi del culto nell arco alpino occidentale dalla preistoria al medioevo. Atti del Convegno in occasione del decennale del Civico Museo Archeologico di Mergozzo (18 ottobre 2014). Mergozzo 2016, 203-222.

${ }^{4}$ See n. 8. 
The subsequent phase is witnessed to by a $70 \mathrm{~cm}$ thick layer accumulated on the previous floor, and by the peculiar context outside of the cave where two burials had been placed. In this phase, datable to the 4th-5th centuries, the area was maybe still considered sacred and the large number of coins laid close to the entrance could be interpreted as votive offerings; ${ }^{45}$ but we cannot rule out the hypothesis that the cave was used as a dwelling place, ${ }^{46}$ because traces of possible remains of artisanal activities can be recognized. ${ }^{47}$

The "Antro di Angera" was certainly a cultic and devotional place and its architectural reshaping is a proof of its long lasting and important frequentation by devotees.

Stefano De Togni

CNRS Université de Bourgogne

France

stefanodetogni@gmail.com

${ }^{45}$ FACChinetTI, G.: Le offerte monetali nel mitreo di Angera. In De MARINIS - MASSA - Pizzo (n. 1) 358-361.

${ }^{46}$ SENA ChIESA, G.: Angera romana: il vicus e l'indagine di scavo. In SENA CHIESA - LAvizZARI PEDRAZZINI (n. 1) LIX-LX. In this case a hoard of coins can be associated with this new use of the site.

${ }^{47}$ According to Gemma Sena Chiesa, remains of iron-working, iron tools and blocks of quartz found in the trench outside of the cave can be interpreted in this way. SENA CHIESA (n. 46) LX. 
